\title{
A CROSS-SECTIONAL STUDY TO ASSESS THE AMOUNT AND RE-UTILISATION OF LEFTOVER FOOD IN TIFFIN BOXES SUPPLIED BY TIFFIN PROVIDERS TO COLLEGE STUDENTS
}

\author{
S. B. Bansal1, Priyanka Mahawar², Deepika Rathore³, Deepti Jaiswal", Ayush Jain ${ }^{5}$, Ayushi Singhal6, Harveer Kushwaha7, Abuzar Asif', \\ Anshika Singh ${ }^{9}$, Siddharth Peddhadda10
}

\begin{abstract}
1 Professor, Department of Community Medicine, MGM Medical College, Indore.
${ }^{2}$ Assistant Professor, Department of Community Medicine, MGM Medical College, Indore. ${ }^{3}$ Postgraduate Student, Department of Community Medicine, MGM Medical College, Indore. ${ }^{4}$ Undregraduate Student, Department of Community Medicine, MGM Medical College, Indore. 5Undregraduate Student, Department of Community Medicine, MGM Medical College, Indore. ${ }^{6}$ Undregraduate Student, Department of Community Medicine, MGM Medical College, Indore. 7Undregraduate Student, Department of Community Medicine, MGM Medical College, Indore. sUndregraduate Student, Department of Community Medicine, MGM Medical College, Indore. ${ }^{9}$ Undregraduate Student, Department of Community Medicine, MGM Medical College, Indore. ${ }^{10}$ Undregraduate Student, Department of Community Medicine, MGM Medical College, Indore.
\end{abstract}

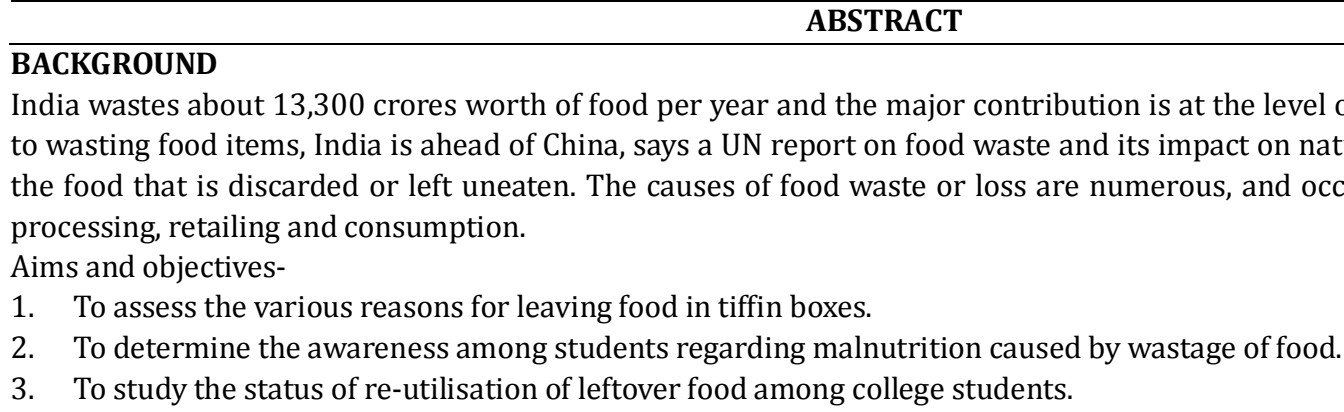

\section{MATERIALS AND METHODS}

It is a cross-sectional study done in a period of 3 months in MGM Medical College, Indore. 180 Students of MGM Medical College were selected as study subjects who were utilising tiffin services for the past 6 months by simple random sampling. A pre-tested semi- structured questionnaire was used to collect information. Verbal informed consent was taken from every student before filling the questionnaires.

\section{RESULTS}

Out of 180 students studied, $45 \%$ of the females waste food, $22 \%$ say they are putting a great deal of effort to reduce food wastage. $65 \%$ of them leave food in their tiffin regularly and $35 \%$ of them are able to finish all the food provided. $14 \%$ of 180 students waste food because the amount given is too much, $5 \%$ waste food because their appetite is less, $1 \%$ waste food because it is cold, $38 \%$ waste because the food is not tasty and 7\% waste food because of lack of variety. Majority of them did not reutilise the wasted food.

\section{CONCLUSION}

Based on our observational study, we have found that majority of the people wasting food were females. Taste of food and excess quantity were the reasons for wastage. A significant number of students were guilty of wasting food and majority of students were willing to adopt various measures to reduce food wastage and also, they were willing to educate others to reduce food wastage and help in combating malnutrition.

\section{KEYWORDS}

Food Wastage, Leftover Food, Malnutrition, Tiffin Services.

HOW TO CITE THIS ARTICLE: Bansal SB, Mahawar P, Rathore D, et al. A cross-sectional study to assess the amount and reutilisation of leftover food in tiffin boxes supplied by tiffin providers to college students. J. Evolution Med. Dent. Sci. 2017;6(90): 6340-6342, DOI: $10.14260 /$ jemds/2017/1379

'Financial or Other Competing Interest': None.

Submission 04-08-2017, Peer Review 07-11-2017,

Acceptance 13-11-2017, Published 20-11-2017.

Corresponding Author:

Dr. Priyanka Mahawar,

Assistant Professor,

Department of Community Medicine,

MGM Medical College.

E-mail: priyankabhupesh@gmail.com

DOI: $10.14260 /$ jemds $/ 2017 / 1379$

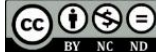

\section{BACKGROUND}

The theme for this year's World Environment Day campaign is 'Think, Eat, Save'. It aims to reduce the food wastage. India ranks 63 among 88 countries in Global Hunger Index.(1) Thus, in a country like India with not much economic development and poor living condition, wasting of food doesnot sounds good and leads to further crippling of economy. Apart from this, India is also considered a country with cultural dominance. Since ages people in India are not allowed to leave uneaten portions in their plate. Food waste refers to the removal of food from the overall supply that is fit for consumption, or which has been spoiled or expired, mainly 
due to economic behaviour, poor stock management or neglect.(2)

The gravity of the problem which is more disheartening is that lot of deforestation is done to get agricultural land and lot of manpower, electricity and water is utilised to grow food and it even does not end here because the government also spends a lot on transportation of produced food, cold storage of these items and then processing it so that it reaches common man. Thus, this study was conducted in MGM Medical College, Indore to study about the amount of leftover food in tiffin boxes, to assess the various reasons for leaving food in tiffin boxes and to determine the awareness among students regarding malnutrition caused by wastage of food.

\section{MATERIALS AND METHODS}

This cross-sectional study was done in MGM Medical College, Indore for a duration of 3 months. 180 college students were selected by simple random sampling who have been utilising tiffin services for the past 6 months and who have given verbal informed consent. A pre-tested semi-structured questionnaire enquiring about the amount and type of food they left, reasons thereof and various measures taken, etc., were administered to the participants and information was collected. Then, data was entered and analysed by SPSS.

\begin{tabular}{|c|c|c|c|}
\hline Sl. No. & Category & $\begin{array}{c}\text { Frequency } \\
\text { N=180 }\end{array}$ & Percentage \\
\hline 1. & Who are able to finish & 63 & 35 \\
\hline 2. & $\begin{array}{c}\text { Who are not able to } \\
\text { finish }\end{array}$ & 117 & 65 \\
\hline \multicolumn{3}{|c|}{$\begin{array}{c}\text { Table 1. Percentage of Participants able to } \\
\text { Finish Food in their Tiffin Boxes }\end{array}$} \\
\hline
\end{tabular}

\begin{tabular}{|c|c|c|c|c|}
\hline $\begin{array}{c}\text { Sl. } \\
\text { No. }\end{array}$ & Category & Male & Female & Total \\
\hline 1. & Food waster & $35(19.4 \%)$ & $82(45 \%)$ & $\mathbf{1 1 7}$ \\
\hline 2. & Non-waster & $40(22 \%)$ & $23(12 \%)$ & $\mathbf{6 3}$ \\
\hline 3. & Total & $\mathbf{7 5}$ & $\mathbf{1 0 5}$ & $\mathbf{1 8 0}$ \\
\hline \multicolumn{5}{|r|}{ Table 2. Proportion of Males and Females who Waste Food } \\
among the Study Subjects \\
\hline
\end{tabular}

\begin{tabular}{|c|c|c|c|}
\hline $\begin{array}{c}\text { Sl. } \\
\text { No. }\end{array}$ & Various Reasons & $\begin{array}{c}\text { Frequency } \\
\mathbf{N = 1 8 0}\end{array}$ & Percentage \\
\hline 1. & $\begin{array}{c}\text { Amount of food is too } \\
\text { much }\end{array}$ & 27 & 14 \\
\hline 2. & Less appetite & 12 & 5 \\
\hline 3. & Cold food & 3 & 1 \\
\hline 4. & Bad taste & 76 & 38 \\
\hline 5. & Lack of variety & 14 & 7 \\
\hline 6. & Non-wasters & 48 & 35 \\
\hline \multicolumn{4}{|c|}{ Table 3. Various Reasons for Leaving Food in Tiffin Box } \\
\hline
\end{tabular}

\section{RESULTS}

Out of 180 participants, majority of students $(117,65 \%)$ leave food in their tiffin and among them $45 \%$ were females. $55 \%$ of the total food wasters belong to the age group 18-23 years, rest $(9 \%)$ were above 23 yrs. $71 \%$ of students left approximately $25 \%$ amount of food provided. Curry and rice are the most common food items left. Most common reasons given by students for wasting their food were bad taste (38\%) followed by excess amount (14\%) and lack of variety (7\%).

It is found that, majority of the students $(66 \%)$ were aware of the fact that food wastage is a cause of malnutrition.
$75.6 \%$ of them feel guilty about wasting food and are willing to reduce food wastage. $22 \%$ say they are putting a great deal of effort to reduce food wastage, 33\% say they make a fair amount of effort, $28 \%$ put a little effort, $7 \%$ say they don't put any effort at all. Lastly, we have also found that among all the wasters, $33 \%$ of students put in a fair amount of effort to reduce food wastage and some of those efforts are: sharing food with friends, giving away leftover food to the needy or stray animals.

\section{DISCUSSION}

Food wastage is a universal problem, in India it is an alarming issue. Indians waste as much food as the whole of United Kingdom consumes. ${ }^{1}$ While we may not be able to reduce food lost during production, we can certainly reduce food at our personal level of food waste. Hence, this study is done to assess the food wastage among the tiffin box users in college students.

In our study, we have found that majority of people who waste food are females that is $45 \%$ of the sample population. The reason for females wasting more food could be due to low appetite as compared to males. In contrast to this, a study done by Cohen et $\mathrm{al}^{3}$ in Boston middle school found that there were no significant differences in food wastage gender wise among school students.

In the present study, it was found that among the total sample taken only $35 \%$ of the students finish the food provided in their tiffin boxes regularly. Among the food wasters i.e. of $65 \%$, most of them leave $25 \%$ of their meal, reason being lack of time due to hectic lecture schedules or might be due to their low appetite due to heavy breakfast or hot sunny weather might be a reason too. Curry/Sabzi is the most wasted food item in the tiffin, the reason of wasting curry may be due to partially cooked curry or may be due to bad taste. Similarly, the study done by Cohen et $\mathrm{al}^{3}$ found that on an average about $60 \%$ of the food served at lunch were consumed. On average, students discarded roughly $19 \%$ of their entrées, $47 \%$ of their fruits, $25 \%$ of their milk and $73 \%$ of their vegetables. Other two studies done by Gracy et al ${ }^{4,5}$ in elementary schools directly estimated foods consumed versus foods served and found that fruits and vegetables served were valid proxies for what was consumed.

Results show that the main reason why students leave the food in their tiffin boxes is the bad taste and also due to the excess amount which is more than their appetite which is similar to the findings of Cohen et al study who also found that foods served were a substantial overestimation for food consumed at lunch. Students would benefit if additional focus was given to the quality and palatability of food.

It was disheartening that $24.4 \%$ of wasters are not even guilty about wasting food, as found in this study.

Among all the students studied, $99 \%$ of them were interested in educating other people to not waste food which will encourage other students also to reduce food wastage and help combat malnutrition. Thus, we should all try to minimise food wastage.

\section{CONCLUSION}

There is a substantial food wastage among tiffin box users in college. Majority of the people wasting food in tiffin boxes are 
females. A significant number of students were guilty of wasting food and majority of students were willing to adopt various measures to reduce food wastage and also, they were willing to educate others to reduce food wastage and help in combating malnutrition. Students would benefit if additional focus was given to the quality and palatability of food provided in tiffin boxes.

\section{Limitations}

This study is done on small sample size due to time constraint. Recall bias of students is not taken into account in results.

\section{Recommendations}

Food wastage cripples a country's economy to an extent that most of us are unaware. Some measures that the government needs to take include containing wastage in transportation, improving storage facilities (the cold storage capacity is $50 \%$ less than the needed capacity and needs to be brought up to world standards). Food processing also needs to be sped up so that food is saved and wasted less to feed more. At personal level, we can avoid food wastage by simply sharing the leftover food with friends or those who are in need. The tiffin provider should be informed about the amount required. Others need to be educated to reduce food wastage.

\section{REFERENCES}

[1] Food wastage in India a serious concern-the CSR Journal thecsrjournal.in/food-wastage-in-India-aserious-concern.

[2] Definitional framework of food loss. Food and agriculture organization of the United Nations, Rome, 2014.

[3] Cohen JF, Richardson S, Austin SB, et al. School lunch waste among middle school students: nutrients consumed and costs. Am J Prev Med 2013;44(2):11421.

[4] Gray C, Lytle LA, Perry C, et al. Fruits and vegetables taken can serve as a proxy measure for amounts eaten in a school lunch. J Am Diet Assoc 2007;107(6):101923.

[5] Gray C, Lytle LA, Mays R, et al. Foods on students' trays when they leave the cafeteria line as a proxy for foods eaten at lunch in a school-based study. J Am Diet Assoc 2002;102(3):407-9. 